\title{
Volumetric changes in acrylic denture base material
}

\author{
Nadira A IIATIM* \\ Sameer M RASIIAD**
}

\begin{abstract}
ABSTRAC'T
Aims of this study are to determine:

a-Three dimensional changes (Volumetric changes) of the internal surfaces of twenty four maxillary acrylic resin complete denture bases in relation to their corresponding master casts, were determined among six patients by using three dimensional measuring machine \{Cordimet 1200$\}$.

b-The maximum dimensional change of the acrylic resin denture that can be allowed to avoid displacement of the tissue.

c- The effect of muco-static impression technique on the tissue displacement.

Three maxillary dentures $\mathrm{A}, \mathrm{B}$, and $\mathrm{C}$ were constructed in the conventional way. Dentures $B$, and $C$ were designed by increasing the space between the internal surface of the denture and the tissue surface of the master cast by using tinfoil $(0.2)$ $\mathrm{mm}$, and (0.3) $\mathrm{mm}$ except the periphery region respectively.

By the aid of computer, three special programs were designed for this study to, calculate the surface area, volumetric changes in acrylic denture base, and to draw any section of the tissue surface of the oral cavity in relation to the tissue surface of the denture every (5) $\mathrm{mm}$ longitudinally, and (2) $\mathrm{mm}$ horizontally,

The results of this study showed that maximum tissue displacement was found in the midline region toward the posterior part of the denture base $(27.465 \mathrm{~mm})$.

The area of tissue displacement was reduced toward the periphery, away from the midine of the maxillary arch. While in the post-dam region, tissue displacement was found in the middle part of the palate

In the periphery region there was a convergence of buccal flanges loward the middle of the denture base

A positive volumetric change in denture base was found in molar region $\left(0.072 \mathrm{~mm}^{3}\right)$. The results of muco-stalic impression technique was a pressure on the tissue to $0.3 \mathrm{~mm}$ vertically lead to have negative volume equal to $\left(0.00 \mathrm{~mm}^{3}\right)$.
\end{abstract} Key Words: Denture base, Volumetric changes, Silicone impression material.

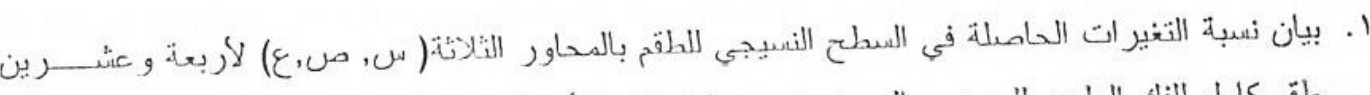

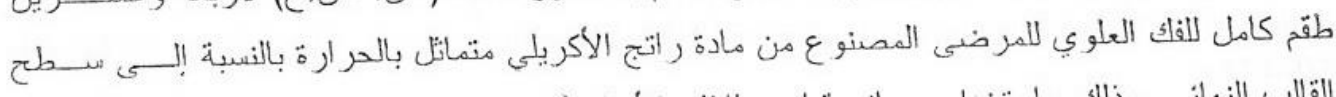

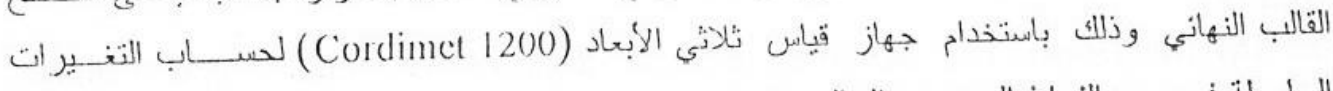

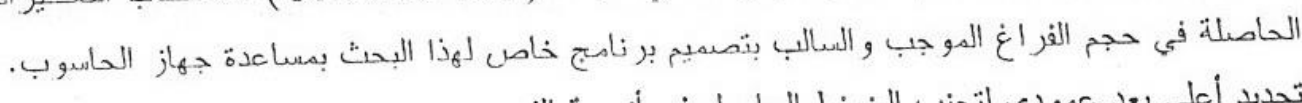

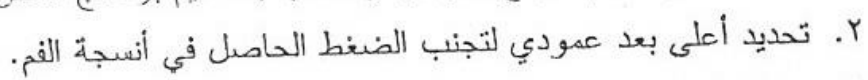

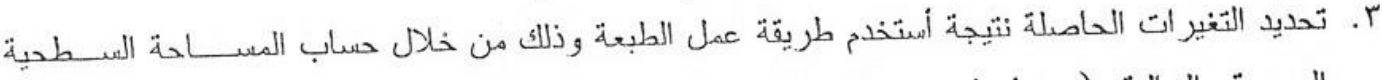
(Muco-static impression technique) باستخدام الحاسوب.

* Nadira Abdul-Ridha IIATIM: BODS. MSc: Assistant Prof. Department of Prosthetic Dentistry. College of Dentistry, University of Mosul. Mosul, IRAQ.

* Sameer Molammad RASHAD: BDS. MSc: Assistant Prof. Department of Prosthetic Dentistry. College of Dentistry, University of Baghdad, Baghdad, IR $\wedge Q$. 


$$
\begin{aligned}
& \text { تم اختيار المرضى فاقدي الأسنان الكاملة للفك العلوي و السفلي وبمواصفات خاصة تم تحدبدها لــــذه. }
\end{aligned}
$$

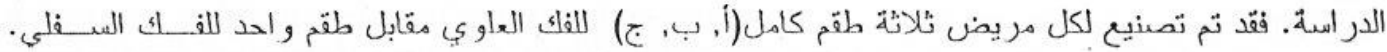

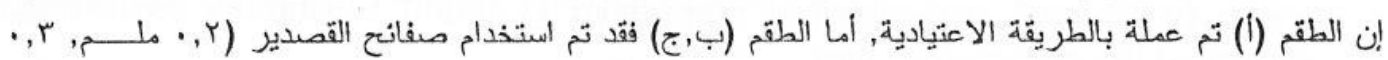

$$
\begin{aligned}
& \text { ملم) } \\
& \text { أثبتت النتانج إن اكثر منطقة تتعرض لضغط نسيجي نتيجة للضغط الحـاصل مــن الطبعـة ووهـن }
\end{aligned}
$$

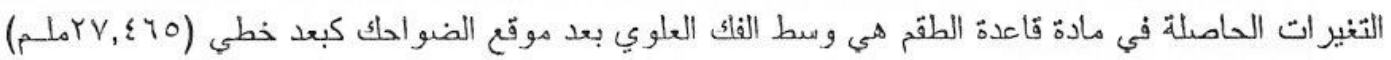

$$
\begin{aligned}
& \text { ويقل هذا التغيير باتجاه حدود الطقم. }
\end{aligned}
$$

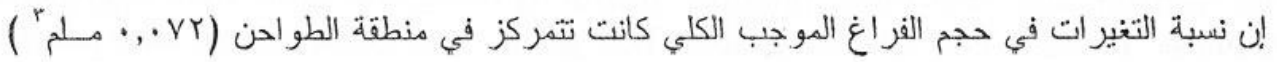

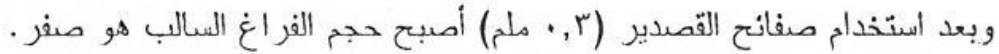

\section{INTRODUCTION}

The improvement of dimensional accuracy of denture base material is one of the requirements of complete denture construction. Most processed resin denture bases do not fit the cast accurately because of polymerization changes in the resin. measured on

Methods of evaluating linear dimensional changes of acrylic resin are

1. Specimens by micrometer caliper ${ }^{(1,2,3,4)}$.

2. Standard cast by micrometer caliper $(5,6,7)$.

3. Metal model of artificial stone duplicate of the American Dental $\Lambda$ ssociation $\Lambda D \wedge$ edentulous ridge die ${ }^{(8.9)}$

4. Stone cast by Comparator device ${ }^{(10,11)}$

Volumetric changes in acrylic denture base in relation to the tissue of the oral cavity were not available in previous studies so the aims of this study are to determine:

1-The three-dimensional changes (Volumetric changes) of the internal surface of the complete denture base in relation to the master cast.

2-Maximum dimensional change of the acrylic resin denture that can be allowed to avoid displacement of the tissue.

3- The effect of muco-static impression technique on the tissue displacement.

\section{MATERIALS AND METIIODS}

Six edentulous patients were selected, two males and four females. The age range was between 45-55 years. All patients were wearing complete maxillary and mandibular dentures for 5-8 years. None of the patients have sever unilateral, bilateral, distal, or anterior undercut or any abnormality in the maxillary arch.

For each patient a spaced special tray with closed periphery of autopolymerizing acrylic resin with four stoppers were done, two on the canine region, and two on the molar region. Final impression of Vinyl silicone (Exaflex, G.C. Dental industrial Crop-Japan) for maxillary arch was poured three times (after 15 minutes, 1 hour, and 2 hours) with dental stones (100 Gm powder to 35 c.c. water ratio). 
For each patient, three maxillary dentures $\mathrm{A}, \mathrm{B}$, and $\mathrm{C}$ were constructed against mandibular denture as follows:

1. Denture $A$ was constructed in the conventional method by applying separating media (cold mold seal which is considered as tinfoil substitute) on the tissue surface of the master stone cast.

2. Denture $\mathrm{B}$ and $\mathrm{C}$ were constructed in the conventional method by using tinfoil $(0.2) \mathrm{mm}$ and $(0.3) \mathrm{mm}$ respectively. It was adapted very well on the tissue surface of the master stone cast except (2) $\mathrm{mm}$ from the deepest point of the periphery and post-dam regions.

3. Three maxillary dentures against one mandibular denture were constructed with same vertical and horizontal relation record by using face bow, semi adjustable articulator devices and special guide. The guide was made of cold cure acrylic resin as a record base on the maxillary cast and stone $\{\mathrm{Val}$ mix $\}$ was applied on the occlusal surface of the mandibular teeth (figure 1).

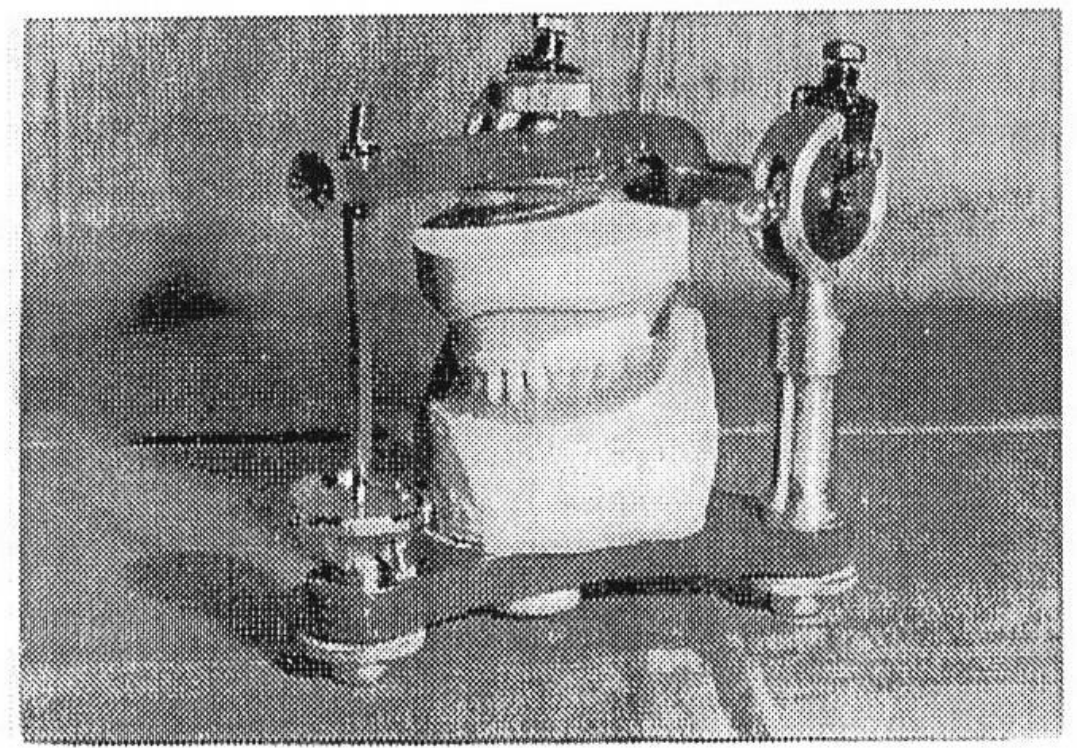

Figure (1): Stone cast with special guide for mounting at the same maxillo-mandibular records

\section{Measurements}

All measurements have been done by using Cordimet $1200^{(12)}$, C.E Johansson program No. 101 available in three axes X, Y, Z, to measure the tissue surface of :

1. Eightecn master stone casts.

2. Eighteen maxillary complete dentures.

Each tissue surface of the master cast, and the denture to be measured, was put on the diabase granite of the 3D measuring machine and held in position by a special metal holder consisting of three adjustable conical metal parts to start from zero plane. 
Four selected landmarks were prepared (one on the incisive papilla, two on the crest of the ridge posteriorly on each side, and the other on the midline) by using stainless steel round bur no. 1 for adjustment.

Measurements were made as follows:

1.In the longitudinal direction from the incisive papilla at the midline to measure each point in the $\mathrm{X}, \mathrm{Y}, \mathrm{Z}$ axes at $2 \mathrm{~mm}$ distance at $\mathrm{X}$-axis.

2. In the transverse direction each $5 \mathrm{~mm}$ in $\mathrm{Y}$-axis on the right and left sides.

3. The periphery delineated as arc, measurement was carried out from the deepest point of the arc in longitudinal direction at $5 \mathrm{~mm}$ in the $X$-axis.

The total number of (196) points was measured in $\mathrm{X}, \mathrm{Y}$, and $\mathrm{Z}$-axes for master cast or the tissue surface of the denture base figure (2).

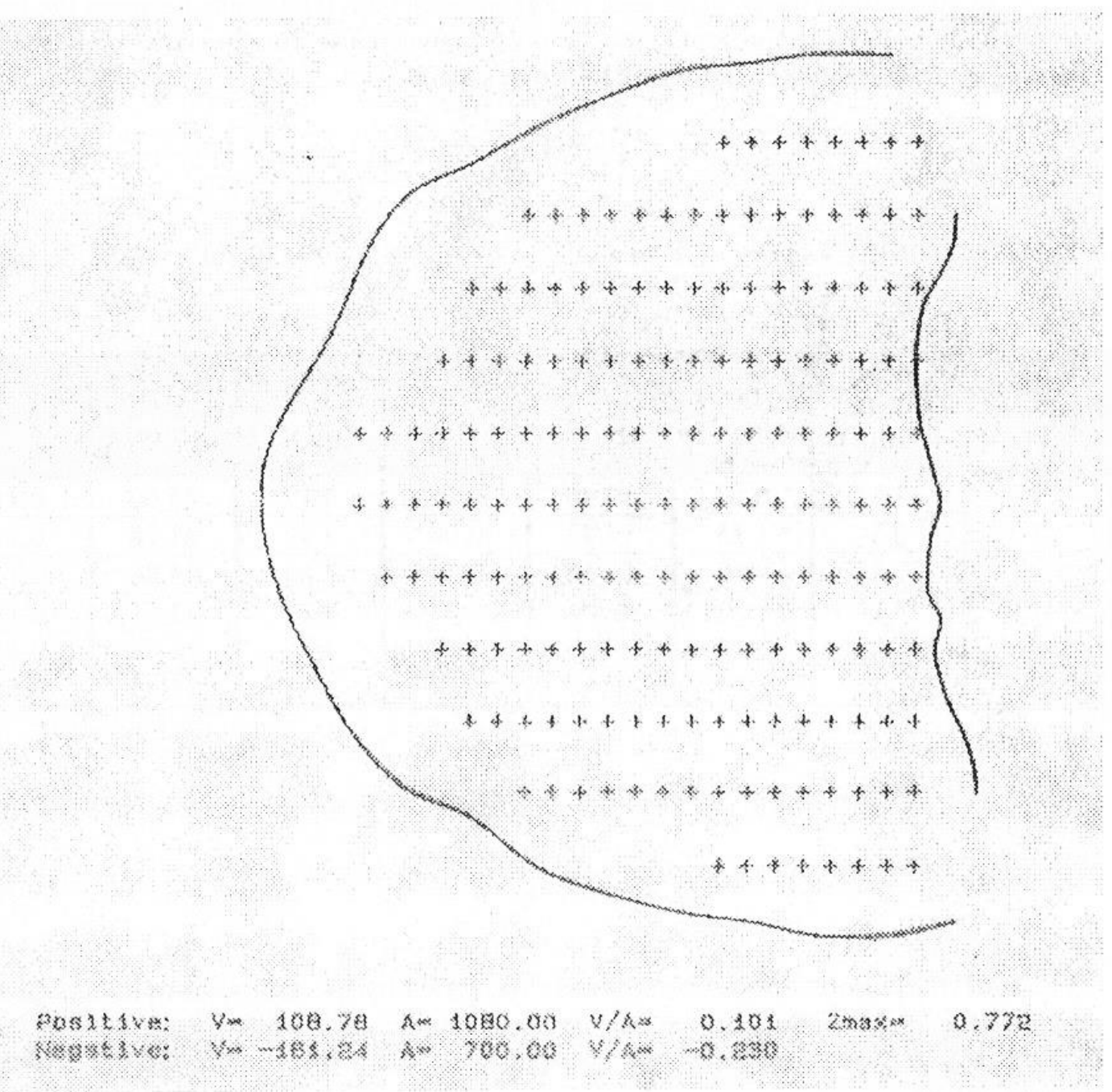

Figure (2): Graphic drawing for points of measurements $\mathrm{X}, \mathrm{Y}$, and $\mathrm{Z}$ axes of each surface of master cast or the tissue surface of the denture 


\section{RESULTS}

The measurements of the three $X, Y$, and $Z$ axes for each point of the master cast or the tissue surface of the denture were calculated by the aid of computer program prepared specially for this study to determine the positive and negative areas depending on these equations:

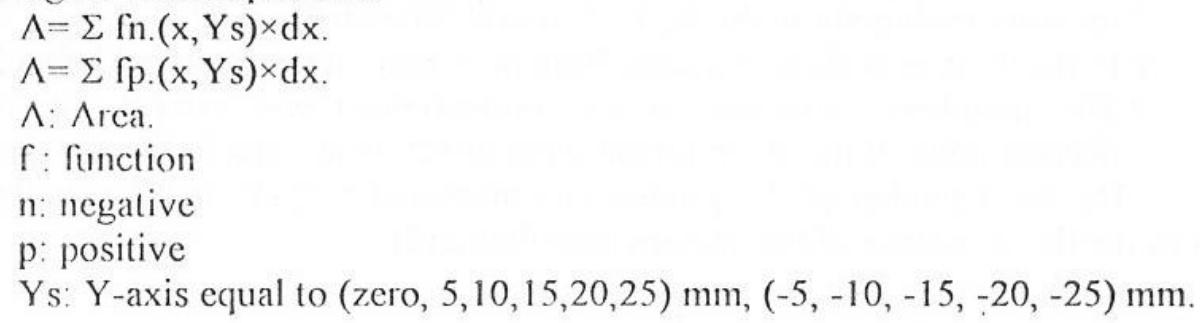

In all sections the positive area (AP) represents the total space between the two surfaces and (NA) represents the contact between the two surface with tissue displacement are tabulated in (table 1) for one section.

Table (1): Positive and negative area in relation to it's length ratio at $Y=0 \mathrm{~mm}$ on the midline

\begin{tabular}{|c|c|c|c|c|c|c|c|}
\hline \multicolumn{2}{|c|}{ Dal of I rinticipanin } & \multirow{2}{*}{ 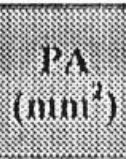 } & \multirow{2}{*}{$\begin{array}{l}\text { (1) } \\
\text { (1) }\end{array}$} & \multirow{2}{*}{ 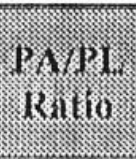 } & \multirow{2}{*}{ (minit) } & \multirow{2}{*}{ (In) } & \multirow{2}{*}{ 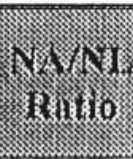 } \\
\hline $\begin{array}{l}\text { Mister } \\
\text { Const }\end{array}$ & Donurin & & & & & & \\
\hline 1 & $1 \mathrm{~A}$ & 0.57 & 10.40 & 0.06 & 4.17 & 25.60 & 0.16 \\
\hline 2 & $2 \Lambda$ & 1.15 & 14.72 & 0.08 & 2.29 & 21.28 & 0.11 \\
\hline 3 & $3 \mathrm{~A}$ & 0.80 & 15.14 & 0.05 & 2.84 & 24.86 & 0.11 \\
\hline 4 & $4 \AA$ & 0.23 & 6.45 & 0.04 & 4.22 & 33.55 & 0.13 \\
\hline 5 & $5 \Lambda$ & 0.08 & 5.35 & 0.02 & 3.70 & 34.65 & 0.11 \\
\hline 6 & $6 \Lambda$ & 1.29 & 15.51 & 0.08 & 2.21 & 21.49 & 0.09 \\
\hline
\end{tabular}

All the results of this study were converted by special program into graphic drawing for each section of the master cast in-relation to the tissue surface of the denture and for post-dam and $\operatorname{Arc}$ (periphery of the master cast and the denture (figures $3,4,5$ ).

Mean of positive area (UN-displaced tissue) to its length was higher in molar region $Y=20 \mathrm{~mm}(0.072 \mathrm{~mm}$.), while in post-dam region tissue displacement was higher in relation to the positive length $(0.085 \mathrm{~mm}$.). This is due to preparation of postdam on the master stone cast. 
Causes of tooth extraction with the no. of teeth for each single cause were shown in table (7). Pulpitis was the most common cause for tooth extraction with a total number of (1020) tecth (34.65\%), followed by periodontal disease (837) teeth $(28.44 \%)$ of the total tooth loss. However, malposed teeth (only 9) showed the least percentage of tecth extracted $(0.30 \%)$.

Table (7): Causes of tooth extraction and the number of tecth for each single cause

\begin{tabular}{|c|c|c|}
\hline Dingousis & 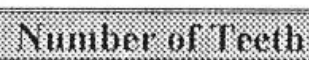 & 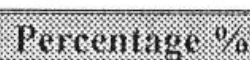 \\
\hline 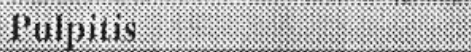 & 1020 & 34.65 \\
\hline 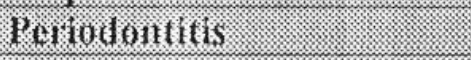 & 837 & 28.44 \\
\hline 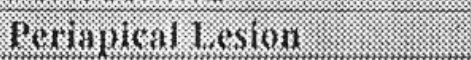 & 381 & 12.94 \\
\hline Bevinilized Tooul & 300 & 10.15 \\
\hline Prostientic: & 237 & 8.05 \\
\hline OMlinodonitio & 75 & 2.54 \\
\hline Fericoronitis & 51 & 1.73 \\
\hline Rerinied Deciluous Tooth & 21 & 0.71 \\
\hline Supcrnumeray, & 12 & 0.40 \\
\hline Malposerl & 9 & 0.30 \\
\hline
\end{tabular}

\section{DISCUSSION}

The results of this study showed that number of males was higher than that of females. This finding was also seen by Allen ${ }^{(11)}$, Cahen et $a l^{(12)}$ and Zaidan ${ }^{(7)}$. However, the results of this study were not in agreement with other studies ${ }^{(1,13,14,15)}$. While the study of Jackson ${ }^{(16)}$, Lundqvist ${ }^{(2)}$, and Sheiham et al. ${ }^{(17)}$ showed that male to female ratio was very similar. The possible explanation for this finding may be due to the fact that female search a conservative treatment earlier than male ${ }^{(7)}$.

Concerning the age groups, the higher $\%$ of tooth loss was seen in first group (15-34 year). This result was also reported by $\Lambda_{1 l e n}{ }^{(11)}$, Krogh ${ }^{(18)}$, Barclay ${ }^{(19)}$, Roder $^{(20)}$, Khalil (1), and Zaidan ${ }^{(7)}$. However, Mathur and Narth ${ }^{(21)}$, and Cahen et $a l^{(12)}$ found that a higher percentage of tooth loss was seen in the last group (more than 75 years). The high perentage of tooth loss may be explained that patients of this group were more susceptible to dental caries than other age groups since the larger number of tooth extraction was due to caries and its sequel ${ }^{(7)}$. In addition, large number of patients were uneducated and of low socio-economic class.

The high percentage (19.06\%) of systemic diseases may be due to the fact that as population ages, the number of systemic diseases will go up, and an increasing number of these individuals will present to the dental office for care ${ }^{(22)}$. Also it may be due to the stress imposed on Iraqi individuals since (1991) were the hard unfair economic sanctions was imposed on Iraq. Meantime, about the same percentage of systemic disease recorded by Khalil ${ }^{(1)}$, and Zaidan ${ }^{(7)}$.

The number of patients with cardiovascular diseases was higher than other diseases, and the highest percentage was shown in the third group (55-74 years), this may be due to that cardiovascular diseases (especially hypertension) cause thickening and hyalinization of vessels wall, narrowing of the lumen and proliferation 


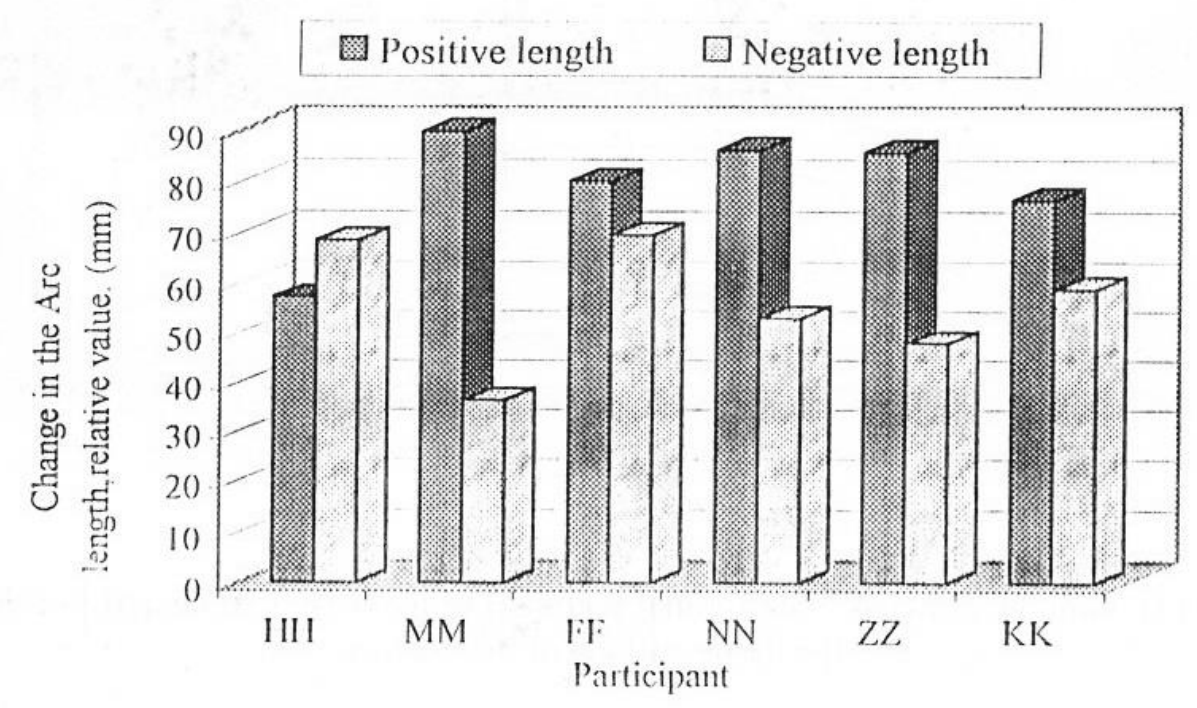

Figure (5): Positive and negative lengths in the periphery region of denture A

Volumetric measurements (V) for six cases for dentures $A, B$, and $C$ were calculated mathematically by special program prepared for this study and depending on the following equations:

$V=\sum f p(x, Y) \cdot d x \cdot d y$

$V=\operatorname{\sum in}(x, Y) \cdot d x \cdot d y$

The results were calculated by the aid of special computer program designed for this study and tabulated in (table 2-6) and (figure 6). PV represents the positive volumetric changes (total space between the two surfaces) in three dimensions X, Y, and $Z$-axes to their surface area $\left(63.953 \mathrm{~mm}^{3}\right)$. The NV represents the negative volumetric changes (total tissue displacement) resulted from muco-static impression technique in three dimension $\mathrm{X}, \mathrm{Y}$, and $\mathrm{Z}$-axes $\left(92.625 \mathrm{~mm}^{3}\right)$.

Table (2): positive volumetric (undisplaced tissue) changes in acrylic denture base $\mathrm{A}$

\begin{tabular}{|c|c|c|c|c|c|}
\hline \multicolumn{2}{|c|}{ Data } & \multirow{2}{*}{ Toun wen } & \multirow{2}{*}{ 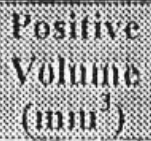 } & \multirow{2}{*}{ (n) } & \multirow{2}{*}{$1 \%$} \\
\hline Ninstit. & Doril 1111 & & & & \\
\hline 1 & $\Lambda 1$ & 23.76 & 85.88 & 1080 & 0.080 \\
\hline 2 & $\mathrm{~A} 2$ & 25.26 & 96.41 & 1130 & 0.085 \\
\hline 3 & A3 & 24.89 & 63.97 & 1100 & 0.058 \\
\hline 1 & $\Lambda 1$ & 28.01 & 72.31 & 880 & 0.082 \\
\hline 5 & A5 & 21.61 & 17.16 & 310 & 0.055 \\
\hline 6 & A6 & 21.91 & 48.00 & 710 & 0.068 \\
\hline
\end{tabular}


Table (3): Negative volumetric changes (tissue displacement) in acrylic denture A

\begin{tabular}{|c|c|c|c|c|c|c|}
\hline \multicolumn{2}{|c|}{ Dil } & \multirow{2}{*}{ 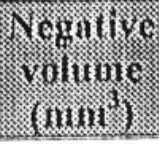 } & \multirow{2}{*}{ (inivi) } & \multirow{2}{*}{ WII } & \multirow{2}{*}{ 2ing } & \multirow{2}{*}{ Hing } \\
\hline Minsin. & benilure & & & & & \\
\hline 1 & $\mathrm{Al}$ & 100.22 & 700 & 0.143 & 0.234 & 0.276 \\
\hline 2 & $\mathrm{~A} 2$ & 79.24 & 840 & 0.094 & 0.224 & 0.278 \\
\hline 3 & $\mathrm{~A} 3$ & 41.17 & 570 & 0.072 & 0.192 & 0.180 \\
\hline 4 & A4 & 131.47 & 1080 & 0.122 & 0.202 & 0.250 \\
\hline 5 & A5 & 116.87 & 1210 & 0.096 & 0.174 & 0.240 \\
\hline 6 & A6 & 86.78 & 860 & 0.101 & 0.190 & 0.210 \\
\hline
\end{tabular}

Table (4): positive volumetric (undisplaced tissue) changes in acrylic denture base B

\begin{tabular}{|c|c|c|c|c|}
\hline \multicolumn{2}{|c|}{10111} & \multirow{2}{*}{ 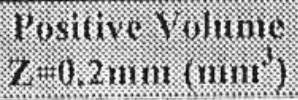 } & \multirow{2}{*}{$\left(11111^{2}\right)$} & \multirow{2}{*}{$1 \%$} \\
\hline Mister: & Sorilur & & & \\
\hline 1 & $\mathrm{Bl}$ & 348.68 & 1610 & 0.217 \\
\hline 2 & $\mathrm{~B} 2$ & 413.23 & 1890 & 0.219 \\
\hline 3 & B3 & 356.80 & 1670 & 0.214 \\
\hline 4 & B4 & 335.70 & 1810 & 0.185 \\
\hline 5 & B5 & 205.39 & 1480 & 0.139 \\
\hline 6 & B6 & 275.32 & 1560 & 0.176 \\
\hline
\end{tabular}

Table (5): Negative volumetric changes (tissue displacement) in acrylic denture base B

\begin{tabular}{|c|c|c|c|c|}
\hline \multicolumn{2}{|c|}{10111} & Joentive volume & 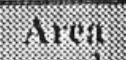 & W/2 \\
\hline Mister: & 1.4num & I. $0.2 \mathrm{mnn}(\mathrm{nm})$ & & \\
\hline 1 & B1 & 7.02 & 170 & 0.041 \\
\hline 2 & B2 & 2.06 & 80 & 0.026 \\
\hline 3 & B3 & 0.00 & 0.00 & 0.000 \\
\hline 4 & B4 & 2.86 & 150 & 0.019 \\
\hline 5 & B5 & 0.90 & 40 & 0.022 \\
\hline 0 & 130, & (). 10 & 10 & 0.010 \\
\hline
\end{tabular}

Table (6): Positive volumetric changes (undisplaced tissue) and negative volume (displaced tissue) in acrylic denture base C

\begin{tabular}{|c|c|c|c|c|c|}
\hline \multicolumn{2}{|c|}{ Dun } & Positive Yolinates & Alica: & Vid & Negatiog yolune \\
\hline Mrister: & Denture & 7. 0.3 min (nini $)$ & $\left.(n+1)^{2}\right)$ & 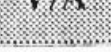 & $\left.(\ln 11)^{2}\right)$ \\
\hline 1 & $\mathrm{Cl}$ & 519.66 & 1780 & 0.292 & 0.00 \\
\hline 2 & $\mathrm{C} 2$ & 608.17 & 1970 & 0.309 & 0.00 \\
\hline 3 & $\mathrm{C} 3$ & 523.80 & 1670) & 0.314 & 0.00 \\
\hline 4 & $\mathrm{C} 4$ & 528.84 & 1960 & 0.270 & 0.00 \\
\hline 5 & $\mathrm{C} 5$ & 356.49 & 1520 & 0.235 & 0.00 \\
\hline 6 & C6 & 432.22 & 1570 & 0.275 & 0.00 \\
\hline
\end{tabular}




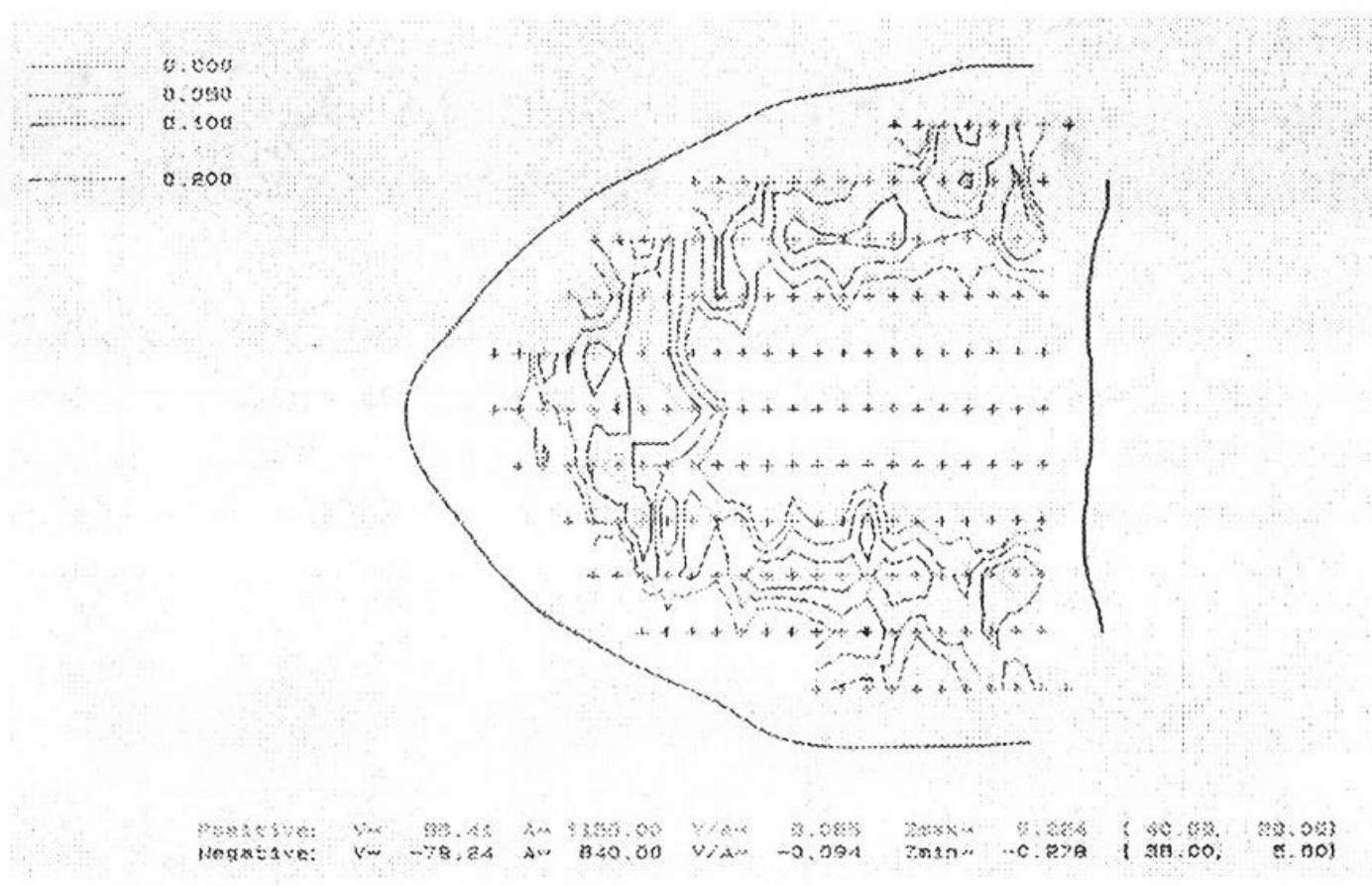

Figure (6): Graphic drawing of positive and negative volumetric changes (undisplaced and displaced tissues) in acrylic denture base $\mathrm{A}$

The student's t-test with degree of freedom (n-1), (n-2) and student's t-test of two sided test $(n-k-1)$ revealed statistically significant dimensional changes in all longitudinal sections, post-dam region, and horizontal dimensional changes in the periphery region with a degree of confidence $\mathrm{P}>0.05$. While for the volumetric changes to their positive or negative areas shows a statistically significant dimensional change with degree of confidence $\mathrm{P}>0.005$ (Tables $7,8,9$ ) and (Figure $7,8,9$ ).

Table (7): Mean and student's t-test of longitudinal sections, post-dam right and left (PR, PL) region, and periphery region (arc)

\begin{tabular}{|c|c|c|c|c|}
\hline S $5011+2$ & 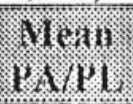 & 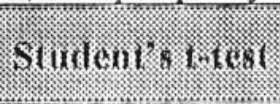 & 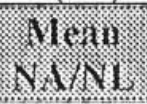 & 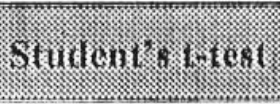 \\
\hline Section, $\mathrm{Y}=0$ & 0.055 & $5.745^{*}$ & 0.118 & $12.070 *$ \\
\hline Section, $Y=10 \mathrm{~mm}$ & 0.056 & $7.926^{*}$ & 0.080 & $5.963^{*}$ \\
\hline Section, $\mathrm{Y}=-10 \mathrm{~mm}$ & 0.058 & $5.414^{*}$ & 0.073 & $6.404^{*}$ \\
\hline Section, $Y=20 \mathrm{~mm}$ & 0.072 & $13.207^{*}$ & 0.073 & $9.135^{*}$ \\
\hline Section, $\mathrm{Y}=-20 \mathrm{~mm}$ & 0.055 & $16.102 *$ & 0.073 & $11.000^{*}$ \\
\hline Section, $X=14 \mathrm{~mm}$ & 0.070 & $4.341^{*}$ & 0.073 & $4.824^{*}$ \\
\hline Section, $X=34 \mathrm{~mm}$ & 0.070 & $6.220 *$ & 0.092 & $6.546^{*}$ \\
\hline PR,PL & 0.067 & $4.535^{*}$ & 0.085 & $9.171^{*}$ \\
\hline Arc & 0.054 & $9.075^{*}$ & 0.045 & $4.566^{*}$ \\
\hline
\end{tabular}

${ }^{*} p>0.05 ; \quad$ PR: Post-dam right side: PL: Post-dam Icft side. 
Figure ( 7): Positive and negative tissue displacement in acrylic denture $A$.

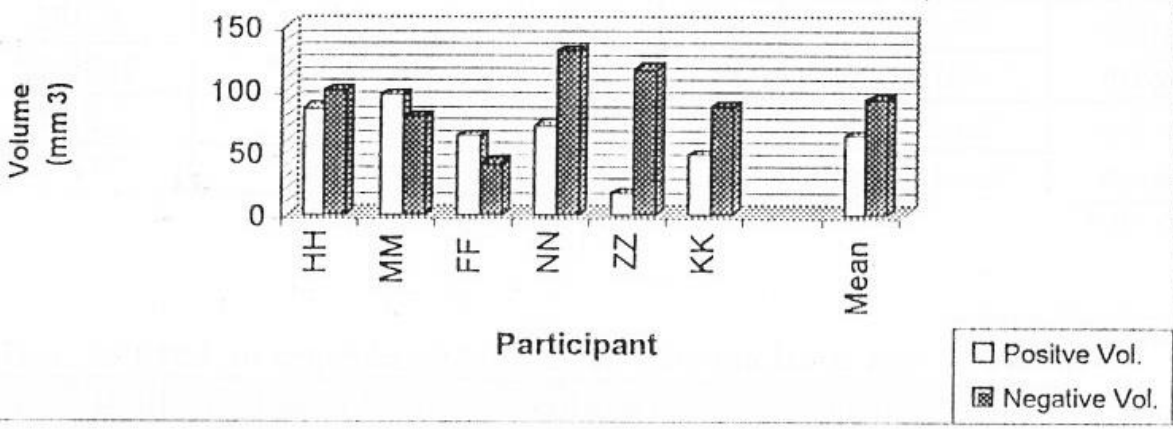

Figure ( 8 ): Negative volumetric changes in dentures A, B, and $\mathrm{C}$.

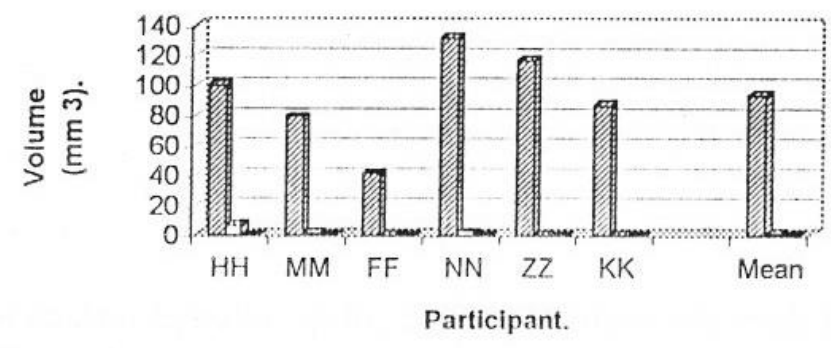

Figure (9): Positive volumetric changes in dentures A, B, and $\mathrm{C}$.

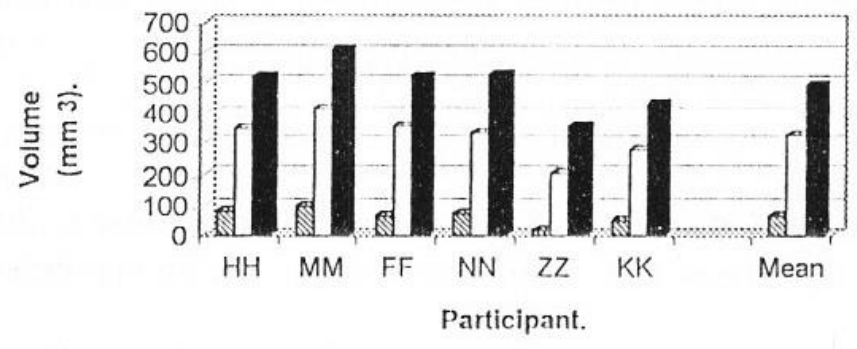


Table (8): Statistical analysis of the periphery and post-dam regions

\begin{tabular}{|c|c|c|c|c|c|c|}
\hline \multicolumn{4}{|c|}{ Sounce } & \multirow{2}{*}{ 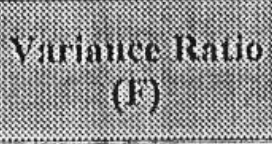 } & \multicolumn{2}{|c|}{ 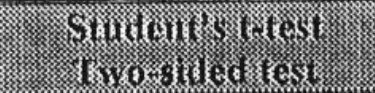 } \\
\hline & y & X/ & $x$ & & tix & (12. \\
\hline \multirow{2}{*}{$\begin{array}{l}\text { Periphery } \\
\text { Region }\end{array}$} & TotalArea & PA & NA & 0.244 & 0.382 & 0.055 \\
\hline & Total Length & $\mathrm{PL}$ & $\mathrm{NL}$ & $7863111.6^{*}$ & $2048.9^{*}$ & $2199.3^{*}$ \\
\hline \multirow{2}{*}{$\begin{array}{l}\text { Post-dam } \\
\text { Region }\end{array}$} & Total Area & $\mathrm{PA}$ & $\mathrm{NA}$ & $22.950^{*}$ & $3.526^{*}$ & $3.254^{*}$ \\
\hline & Total Length & $\mathrm{PL}$ & $\mathrm{NL}$ & $179809.67^{*}$ & $341.2^{*}$ & $344.57^{*}$ \\
\hline
\end{tabular}

${ }^{*} p>0.05$

Table (9): Statistical analysis of volumetric changes in dentures A, B, and C

\begin{tabular}{|c|c|c|c|}
\hline Sources & Denture & Meail & Student's It tedt \\
\hline Positive Volume & $\Lambda$ & 63.955 & $5.506^{*}$ \\
\hline Positive Volume & B & 322.520 & $10.912^{*}$ \\
\hline Positive Volume & $\mathrm{C}$ & 494.863 & $13.811^{*}$ \\
\hline Positive V/A & $A$ & 0.071 & $13.551^{*}$ \\
\hline Positive V/A & B & 0.192 & $14.919^{*}$ \\
\hline Positive V/A & $\mathrm{C}$ & 0.283 & $23.725^{*}$ \\
\hline
\end{tabular}

\section{DISCUSSION}

This study of three-dimensional changes of the internal surface of the denture base in relation to the master cast shows a positive and negative area. The maximum negative area (tissue displacement) was found in the midline region on distance $(X=18-24) \mathrm{mm}$ toward the posterior part of the denture base. Displacement of the tissue was due to dimensional changes in acrylic resin denture base, besides that this area histologically composes of thin layer of submucosa ${ }^{(12,13)}$ table (1) and figure (3).

In section toward the outside, the amount of negative length in which tissue displaced was reduced in relation to the positive length, while in section $(Y=20) \mathrm{mm}$ of all cases showed tissue displacement in few points. (figure 3 ).

Sections in primary stress bearing area showed a space between the two surfaces and this is due to presence of thick submucosa with areolar tissue that can be displaced $^{(13,14)}$

In transverse sections in cuspid and first molar regions there was tissue displacement in mid section.

In first molar region there was a space laterally, this is due to dimensional changes in acrylic denture base and tissue displacement during impression making respectively (figure 3 ).

In post-dam region tissue displacement was found in the middle part, this is due to dimensional changes in acrylic denture base and presence of thick loose areolar connective tissue ${ }^{(13,15,16)}$, that can be displaced without trauma by the complete denture to improve posterior palatal seal ${ }^{(15)}$ (Iigure 4), while laterally there was a space. 
In Periphery region there was a convergence of the buccal flanges toward the midline $^{(17)}$ (figure 4).

Volumetric changes of the internal surface of the denture base $\mathrm{A}$ in relation to the master cast and denture $\mathrm{B}$ and $\mathrm{C}$ showed highly significant relation (table 8,9). Tissue displacement was found in the midline of the palatal region, relief area, and part of the secondary stress bearing area. This is due to the dimensional changes in denture base and histologically the tissue is composed of thin layer of submucosa.

Antero-lateral and postero-lateral areas of the hard palate showed no displacement ${ }^{(13)}$ (figure 6) except case No. (5) with negative volume more than positive volume (figure 9) because this study depends on clinical findings. While complete relief between the internal surface of the denture and tissue of the maxillary arch was found after using of tinfoil $(0.3) \mathrm{mm}$. This identifies that there was a pressure resulted from mucostatic impression technique on the tissue to level of $(0.3)$ $\mathrm{mm}$.

\section{CONCLUSION}

1. Maximum tissue displacement was found in the midline region, due to dimensional changes in acrylic denture base.

2. Positive area (longitudinal and horizontal sections) (undisplaced tissue) was found in the primary and secondary stress bearing areas, this is due to tissue displacement during impression making.

3. Area of tissue displacement in post-dam region was present due to histological structure.

4. Volumetric changes in denture base found in midline, and relief areas with tissue displacement. Positive volumetric changes found in primary and secondary stress bearing areas. There was a space or no tissue displacement due to histological structure.

5. There was a pressure with muco-static impression technique to $0.3 \mathrm{~mm}$ vertical distance.

\section{RETERENCES}

1. Sweeny WT. Denture base material: Acrylic resins. J Am Dent Assoc. 1939; 26: 1863.

2. Becker CM, Smith DE, Nicholls J1. The comparison of denture base processing techniques. Part II. Dimensional changes due to processing. J Prosthet Dent. 1977; 37: 450 .

3. Faraj SAA. The effect of processing temperatures on the exotherm, porosity and properties of acrylic denture base. Br Dent J. 1979; 147: 209.

4. Wolfaardt J, Jones PC, Fatti $\mathrm{F}$. The influence of processing variables on dimensional changes of heat cured poly (methyl methacrylate). J Prosthet Dent. 1986; 55: 518.

5. Skinner FW. Acrylic denture base materials their physical properties and manipulation. J Prosthet Dent. 1951; 1: 161.

6. Woelfel JB, Paffenbarger GC. Expanding and shrinkage 7-year old dentures: report of cases. J Am Dent Assoc. 1970; 81: 1342.

7. Firtell DN, Green AJ, Elahi JM. Posterior peripheral seal distortion relation to processing temperature. J Prosthet Dent. 1981; 45: 598. 
8. Sweeny WT, Paffenbager GC, Beall JR. Acrylic resins for dentures. J Am Dent Assoc. 1942; 29: 7 .

9. Skinner FW, Cooper EN. Physical properties of denture resins. Part 1. Curing shrinkage and water sorption. J Am Dent Assoc. 1943; 30: 1845.

10. Woelfel JB, Paffenbarger GC. Dimensional changes occurring in artificial dentures. JProsthet Dent. 1959; 9: 451.

11. Woelfel JB, Paffenbarger GC, Sweeny WT. Dimensional changes in complete dentures on drying wetting and heating in water. J Am Dent Assoc. 1962; 65: 495.

12. Elshennawy AK, Ham I, Cohen PH. Evaluating the performance of coordinate measuring machine. Quality Prog. 1988; Jan: 59.

13. Zarb GA, Bolender CL, Carlsson GE. Boucher's Prosthodontic Treatment for Edentulous Patients. $11^{\text {th }}$ Edn. The Mosby Co. 1997; Pp: 29, 151, 173, 382.

14. Teraoka F, Takahashi $\mathrm{J}$. Controlled polymerization system for fabricating precise dentures. J Prosthet Dent. 2000; 83(5): 514-520.

15. Woelfel JB. Newer materials and techniques in prosthetic resin materials. J Am Dent Assoc. 1971; 15:67.

16. Watt DM, Macgregor AR. Designing Complete Dentures. $3^{\text {rd }}$ Edn. WB Saunders Co. 1976; Pp: 79-86.

17. Abdel-Hakim AM, Abdallah SA,Mohamed GA. Displacement of border tissues during final impression procedures. JProsthet Dent. 1994; 71: 133-138. 